\title{
A new locus for non-syndromal, autosomal recessive, sensorineural hearing loss (DFNB16) maps to human chromosome 15q21-q22
}

D A Campbell, D P McHale, K A Brown, L M Moynihan, M Houseman, G Karbani, G Parry, A H Janjua, V Newton, L Al-Gazali, A F Markham, N J Lench, R F Mueller

Molecular Medicine Unit, St James's

University Hospital, Leeds LS9 7TF, UK D A Campbell

D P McHale

K A Brown

L M Moynihan

M Houseman

A F Markham

N J Lench

Yorkshire Regional Clinical Genetics

Service, St James's

University Hospital,

Leeds LS9 7TF, UK

D P McHale

G Karbani

R F Mueller

Department of

Paediatrics, St Luke's

Hospital, Bradford,

UK

G Parry

A H Janjua

Centre for Audiology,

University of

Manchester,

Manchester, UK

V Newton

Department of

Paediatrics, United

Arab Emirates

University, Al Ain,

United Arab Emirates

L Al-Gazali

Correspondence to

Professor Mueller.

Received 17 April 1997 Revised version accepted for publication 4 June 1997

\begin{abstract}
Non-syndromal, recessive deafness (NSRD) is the most common form of inherited deafness or hearing impairment in humans. NSRD is genetically heterogeneous and it has been estimated that as many as $\mathbf{3 5}$ different loci may be involved. We report the mapping of a novel locus for autosomal recessive, non-syndromal deafness (DFNB16) in three consanguineous families originating from Pakistan and the Middle East. Using multipoint analysis (HOMOZIMAPMAKER) a maximum combined lod score of 6.5 was obtained for the interval D15S1039D15S123. Recombination events and haplotype analysis define a 12-14 cM critical region between the markers D15S1039 and D15S155 on chromosome 15q15-q21. († Med Genet 1997;34:1015-1017)
\end{abstract}

Keywords: sensorineural deafness; autosomal recessive; autozygosity mapping

Severe or profound congenital sensorineural deafness affects between $1 / 1000$ and $1 / 2000$ live births. ${ }^{1}$ Epidemiological studies suggest that there is a hereditary cause in $20-60 \%$ of cases, an acquired cause in $20-40 \%$, and an unknown cause in the remaining $20-40 \%$. Of the inherited cases, $59-85 \%$ are autosomal recessive and $33 \%$ are autosomal dominant, with $\mathrm{X}$ linked and mitochondrial inheritance accounting for the remainder. Autosomal recessive forms of deafness, thought to arise almost exclusively from cochlear defects, are the most severe forms and account for nearly all profound congenital deafness. Segregation studies have implicated the involvement of at least five common genes and possibly as many as 35 genes in total. ${ }^{2}$ To date, 13 autosomal recessive loci (DFNB1-13) have been mapped using inbred families or population isolates. ${ }^{3-14}$ We describe a novel locus for NSRD mapping to chromosome 15q15-q21 in families originating from Pakistan, Palestine, and Syria.

We screened 29 Pakistani families and 12 Middle Eastern families for linkage to known autosomal recessive (DFNB1-9) and autosomal dominant, non-syndromic deafness loci (DFNA1-8) using microsatellite markers flanking each locus. ${ }^{2}$ Initial results indicated that three families had genotypes consistent with linkage to the DNA markers D15S123 and D15S132. These markers had been reported to define a putative dominant, nonsyndromal deafness locus in an Austrian family, DFNA8. ${ }^{15}$ However, further analysis indicated that the family in fact showed linkage to chromosome $11 \mathrm{q} .{ }^{16}$ Accordingly, DFNA8 was reassigned to chromosome $11 \mathrm{q} .{ }^{2}$ To test the validity of our initial results, we analysed five additional microsatellite DNA markers spanning a $30 \mathrm{cM}$ region of chromosome 15q21-q22: D15S994, D15S1039, D15S155, D15S997, and D15S125. DNA marker genotypes for each pedigree are shown in fig 1 . Two point linkage analysis was performed for each marker using LIPED and the combined values are shown in table 1. Multipoint analysis was performed for each family using the HOMOZ/MAPMAKER ${ }^{17}$ programs and the maximum combined lod score is shown in fig 2 . In classical linkage analysis, the minimal critical region can only be determined using recombination events by looking for obligatory crossovers within the marker haplotypes. In autozygosity mapping, the boundaries of the minimal critical region are defined by the loss of homozygosity of the markers (smallest region of homozygosity) in affected subjects. The smallest region of homozygosity in our families is seen in family 3 between markers D15S132 and D15S155, a region of approximately $12-14 \mathrm{cM}$. No common haplotype was observed between the two families from Palestine and Syria. However, higher density mapping of the newly defined critical region may show an ancestral haplotype.

Non-syndromal deafness most commonly occurs sporadically, that is, as an isolated case within a family. It is not usually possible to discriminate reliably in such a family between an acquired or genetic cause purely on clinical or audiological grounds such as age of onset, severity of hearing impairment, or shape of the audiogram. The chance of recurrence of deafness in subsequent offspring in this situation is

Table 1 Combined two point lod scores for families 1-3

\begin{tabular}{lllllll}
\hline \multirow{7}{*}{$\begin{array}{l}\text { DNA } \\
\text { marker }\end{array}$} & 0 & 0.05 & 0.1 & 0.2 & 0.3 & 0.4 \\
\cline { 2 - 7 } & 0 Decombination fraction $(\theta)$ \\
\hline D15S994 & -6.69 & 0.573 & 1.041 & 1.078 & 0.743 & 0.314 \\
D15S132 & 1.859 & 2.766 & 2.614 & 2.011 & 1.277 & 0.534 \\
D15S1039 & -3.46 & 2.055 & 2.124 & 1.686 & 1.046 & 0.415 \\
D15S123 & 4.238 & 3.756 & 3.269 & 2.604 & 1.352 & 0.519 \\
D15S1028 & 3.635 & 3.221 & 2.805 & 1.982 & 1.198 & 0.5 \\
D15S155 & -26.5 & -3.99 & -2.72 & -0.83 & -0.29 & -0.086 \\
D15S997 & -31.1 & -3.81 & -2.22 & -0.87 & -0.31 & -0.07 \\
D15S125 & -8.66 & -1.53 & -1.17 & -0.33 & -0.14 & -0.06
\end{tabular}


Family 1

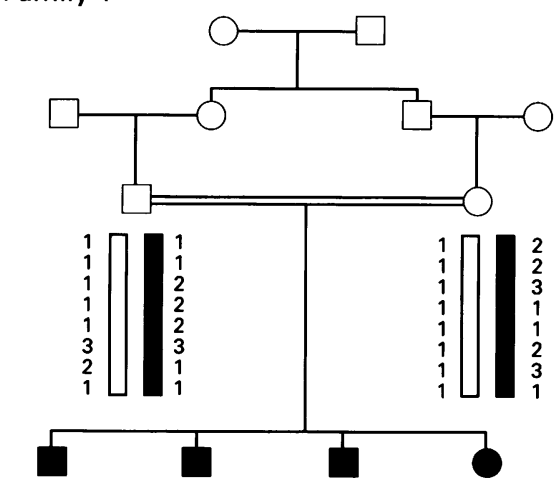

$\left.\begin{array}{l}1 \\ 1 \\ 1 \\ 1 \\ 1 \\ 3 \\ 2 \\ 1\end{array}\right] \square\left[\begin{array}{l}1 \\ 1 \\ 1 \\ 1 \\ 1 \\ 2 \\ 3 \\ 1\end{array}\right.$
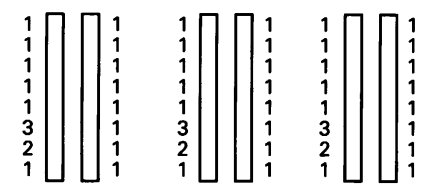

Family 3

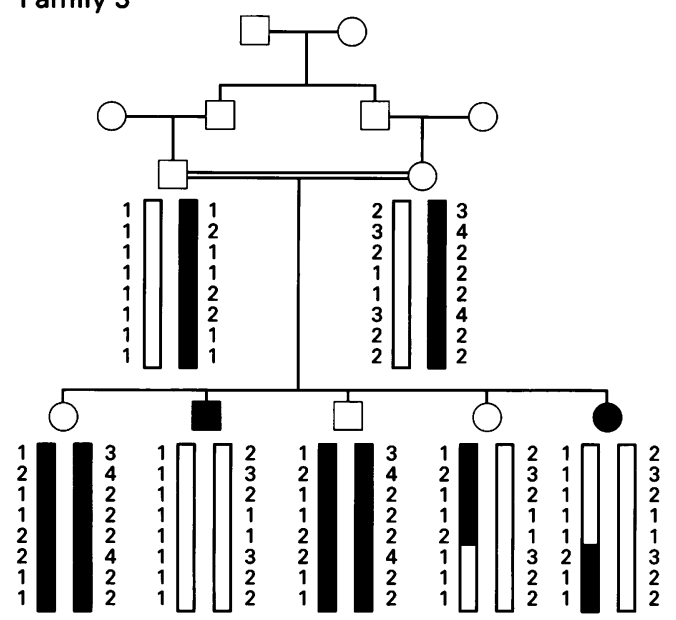

Figure 1 Genotype data for families showing linkage to DFNB16.

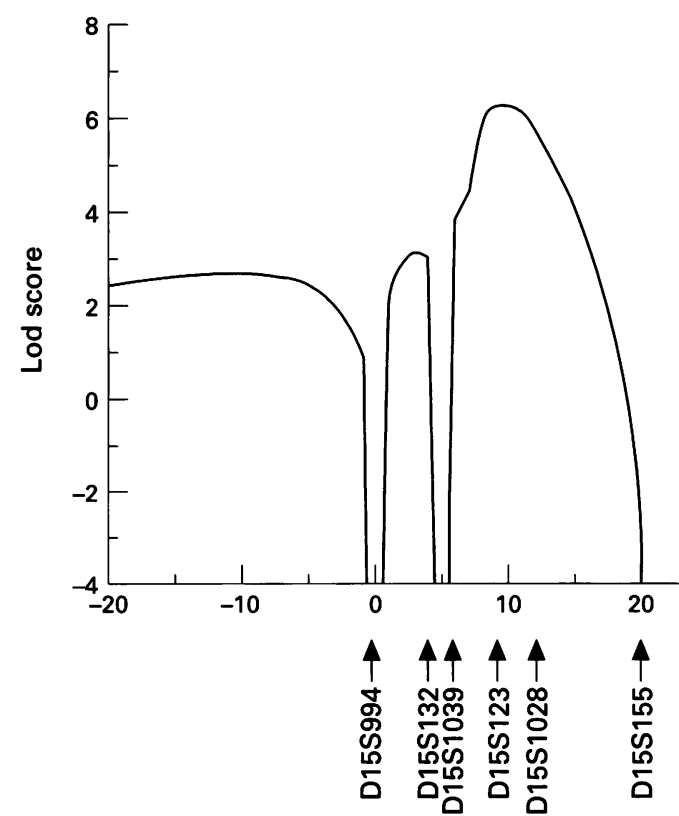

Genetic distance (cM)

Figure 2 Graph showing maximum combined multipoint lod score.

\begin{tabular}{|ll|}
\hline Marker order & \\
D15S1039 & $\square$ Unaffected male \\
D15S132 & $\bigcirc$ Unaffected female \\
D15S123 & Affected \\
D15S1028 & $\square \begin{array}{l}\text { High risk } \\
\text { haplotype } \\
\text { D15S155 }\end{array}$ \\
D15S997 & $\begin{array}{l}\text { Low risk } \\
\text { haplotype } \\
\text { D15S125 }\end{array}$ \\
\hline
\end{tabular}

Family 2
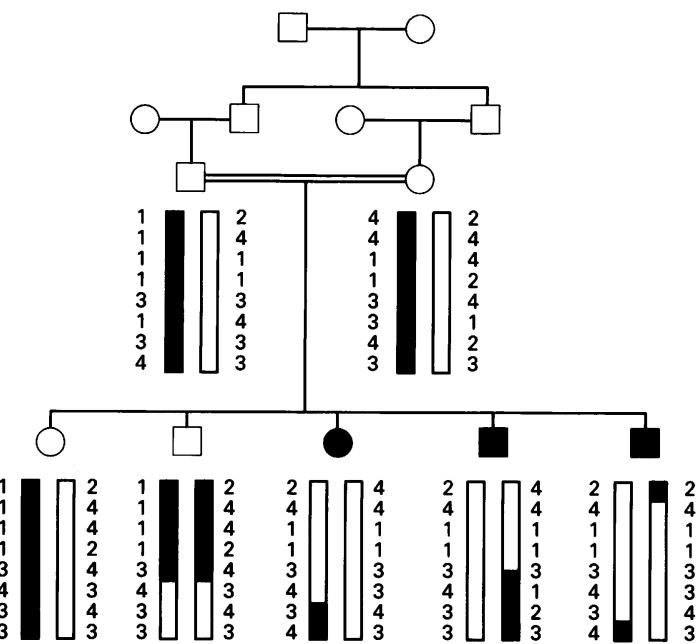

based on empirical figures, that is, the observed recurrence of deafness in such families. Estimates of the relative contribution of individual DFNB loci to non-syndromal deafness within different populations are limited. A study of markers linked to DFNB1 in 19 consanguineous New Zealand families of western European origin has shown cosegregation of the same alleles in affected subjects consistent with approximately one half of the families segregating DFNB1.$^{18} \mathrm{~A}$ separate study estimated that $60 \%$ of families of Mediterranean origin are linked to DFNB1. ${ }^{19}$ However, studies of 26 families of southern Indian origin failed to detect any DFNB1 linkage. ${ }^{4}$ In our own study, one of 29 families originating from Pakistan and two of 12 families from the Middle East are linked to DFNB16. Clearly, only when all the genes responsible for non-syndromal deafness have been identified and mutation analysis performed will it be possible to gain a true estimate of the relative contribution of DFNB loci in different ethnic populations. The identification of the genes responsible for NSRD will also allow more accurate genetic counselling.

Recently it has been shown that Usher syndrome IB is caused by mutations in the 
myosin VIIa gene. ${ }^{20}$ Myosin VIIa belongs to the unconventional myosin group of proteins and is localised to the hair cells of the cochlear and the pigmented cells of the retina. In mice, unconventional myosins fall into six groups and at least 16 different genes have been mapped. ${ }^{21}$ The map locations of five of these genes have been identified in humans including two, myosin IC and myosin VA/VB, which map to chromosome $15 \mathrm{q} 21-\mathrm{q} 22 .{ }^{21}$ As such, these represent plausible candidate genes for the DFNB16 locus.

Work in the authors' laboratories is supported by the Wellcome Trust, Medical Research Council, Defeating Deafness, Northern and Yorkshire Regional Health Authority, and the West Riding Medical Research Trust.

1 Petit C. Genes responsible for human hereditary deafness: symphony of a thousand. Nat Genet 1996;14:385-91.

2 Van Camp G, Willems PJ, Smith RJH. Nonsyndromic hearing impairment: unparalleled heterogeneity. $\mathrm{Am} \mathcal{f} \mathrm{Hum}$ Genet 1997;60:758-64.

3 Baldwin C, Weiss S, Farrer L, et al. Linkage of congenital recessive deafness (DFNB4) to chromosome 7q31 and evidence for genetic heterogeneity in the Middle Eastern dence for genetic heterogeneity in the Middle East

4 Fukushima K, Arabandi R, Srisailapathy C, et al. Consanguineous nuclear families used to identify a new locus for guineous nuclear families used to identify a new locus for recessive non-syndro

5 Fukushima K, Ramesh A, Srisailapathy CR, et al. An autosomal recessive non-syndromic form of sensorineural hea ing loss maps to 3p-DFNB6. Genome Res 1995;5:305-8.

$6 \mathrm{Jain} P$, Fukushima K, Deshmukh D, et al. A human recessive neurosensory non-syndromic hearing impairment locus is a potential homologue of the murine deafness (dn) locus. Hum Mol Genet 1995;4:2391-4.

7 Veske A, Oehlmann R, Younus F, et al. Autosomal recessive non-syndromic deafness locus (DFNB8) maps on chromosome 21q22 in a large consanguineous kindred from Pakistan. Hum Mol Genet 1996;5:165-8.

8 Bonne-Tamir B, DeStefano AL, Briggs CE, et al. Linkage of congenital recessive deafness (gene DFNB10) to chromosome 21q22.3. Am f Hum Genet 1996;58:1254-9.
9 Chaib H, Place C, Salem N, et al. A gene responsible for a sensorineural nonsyndromic recessive deafness maps to chromosome 2p22-23. Hum Mol Genet 1996;5:155-8.

10 Scott DA, Carmi R, Elbedour K, Yosefsberg S, Stone EM Sheffield VC. An autosomal recessive nonsyndromichearing-loss locus identified by DNA pooling using two inbred Bedouin kindreds. Am f Hum Genet 1996;59:38591.

11 Chaib H, Place C, Salem N, et al. Mapping of DFNB12, a gene for a non-syndromal autosomal recessive deafness, to gene for a non-syndromal autosomal recessive deafness,

12 Guilford P, Ben Arab S, Blanchard S, et al. A non-syndromic form of neurosensory, recessive deafness maps to the pericentromeric region of chromosome 13q. Nat Genet 1994;6 24-8.

13 Guilford P, Ayadi H, Blanchard S, et al. A human gene responsible for neurosensory, non-syndromic recessive deafness is a candidate homologue of the mouse $s h-1$ gene. Hum Mol Genet 1994;3:989-93.

14 Friedman TB, Liang Y, Weber J, et al. A gene for congenital, recessive deafness DFNB3 maps to the pericentromeric recessive deafness DFNB3 maps to the pericentr
region of chromosome 17. Nat Genet 1995;9:86-91.

15 Kirshhofer K, Hoover DM, Kenyon JB, et al. Localisation of a gene responsible for an autosomal dominant nonsyndromic sensorineural hearing loss to chromosome 15 . The molecular biology of hearing and deafness meeting, Bethesda, USA, 1995.

16 Kirshhofer K, Kenyon JB, Hoover DM, et al. Autosomaldominant congenital severe sensorineural hearing loss: localisation of a disease gene to chromosome $11 \mathrm{q}$ by the European Workgroup on Genetics of Hearing Impairment, the European Workg

17 Kruglyak L, Daly MJ, Lander ES. Rapid multipoint linkage analysis of recessive traits in nuclear families, including homozygosity mapping. Am $\mathcal{f}$ Hum Genet 1995;56:519-27.

18 Maw MA, Allen-Powell DR, Goodey RJ, et al. The contribution of the DFNB1 locus to neurosensory deafness in a caucasian population. Am f Hum Genet 1995;57:62935.

19 Gasparini P, Estivill X, Volpini A, et al. Linkage of DFNB1 to non-syndromic neurosensory autosomal recessive deaf to non-syndromic neurosensory autosomal recessive deafness in M.

20 Weil D, Blanchard S, Kaplan J, et al. Defective myosin VIIA gene responsible for Usher syndrome type 1B. Nature 1995;374:60-1.

21 Hasson T, Skowron JF, Gilbert DJ, et al. Mapping of unconventional myosins in mouse and human. Genomics 1996;36: 431-9. 